\title{
BCL2 Gene Amplification
}

National Cancer Institute

\section{Source}

National Cancer Institute. BCL2 Gene Amplification. NCI Thesaurus. Code C132021.

A molecular genetic abnormality indicating the presence of multiple copies of the BCL2 gene. 